\title{
Carbon Deposition Diagnostics for Reliability and State-of-Health Assessment of SOFC
}

Ploner, A.; Hagen, A.; Hauch, A.

Published in:

E C S Transactions

Link to article, DOI:

$10.1149 / 08504.0025$ ecst

Publication date:

2018

Document Version

Peer reviewed version

Link back to DTU Orbit

Citation (APA):

Ploner, A., Hagen, A., \& Hauch, A. (2018). Carbon Deposition Diagnostics for Reliability and State-of-Health Assessment of SOFC. E C S Transactions, 85(4), 25-32. https://doi.org/10.1149/08504.0025ecst

\section{General rights}

Copyright and moral rights for the publications made accessible in the public portal are retained by the authors and/or other copyright owners and it is a condition of accessing publications that users recognise and abide by the legal requirements associated with these rights.

- Users may download and print one copy of any publication from the public portal for the purpose of private study or research.

- You may not further distribute the material or use it for any profit-making activity or commercial gain

- You may freely distribute the URL identifying the publication in the public portal

If you believe that this document breaches copyright please contact us providing details, and we will remove access to the work immediately and investigate your claim. 


\title{
Carbon deposition diagnostics for reliability and state-of-health assessment of
} SOFC

\author{
A. Ploner ${ }^{\mathrm{a}}$, A. Hagen ${ }^{\mathrm{a}}$, A. Hauch ${ }^{\mathrm{a}}$
}

Department of Energy Conversion and Storage, Technical University of Denmark, Roskilde 4000, Denmark

Operation of Solid Oxide Fuel Cells (SOFCs) with carbon-based fuels is a major advantage of this specific fuel cell technology. Yet, the use of carbon-containing fuels can lead to deactivation of the cell if carbon deposition occurs. Therefore, this study simulates failure on a Ni-YSZ supported cell under steam reforming conditions by stopping the steam supply and investigates the cell voltage and temperature responses due to this fault. Simultaneously, timedependent electrochemical impedance spectroscopy (EIS) monitoring during cell operation was performed which could be correlated to two processes, one mainly originating from support layer and another from the active anode layer of the cell in a Ni-YSZ supported cell. Monitoring via EIS may therefore be used to allow recognition of carbon deposition in due course and give the opportunity to counteract before detrimental failure occurs.

\section{Introduction}

SOFCs are a promising power converting alternative for various mobile and stationary applications. The high operating temperature of $700-900^{\circ} \mathrm{C}$ and the Ni-based fuel electrode permits SOFCs to be operated directly on hydrocarbon based fuels and not only on hydrogen. This option is known as direct internal reforming (DIR). Most commonly steam and methane are directly fed to the fuel electrode and catalytically converted to hydrogen and carbon monoxide via steam reforming and the water-gas-shift reaction on the active $\mathrm{Ni}$ in the SOFC. This fuel flexibility is beneficial for a variety of applications but introduces an additional potential possible cause of degradation, known as 'coking'. Coking in SOFC, operated under steam reforming conditions, may occur due to following reactions:

$$
\begin{aligned}
& \mathrm{CH}_{4} \rightarrow 2 \mathrm{H}_{2}+\mathrm{C}_{(\mathrm{s})} \\
& 2 \mathrm{CO} \rightarrow \mathrm{CO}_{2}+\mathrm{C}_{(\mathrm{s})} \\
& \mathrm{CO}+\mathrm{H}_{2} \rightarrow \mathrm{H}_{2} \mathrm{O}+\mathrm{C}_{(\mathrm{s})}
\end{aligned}
$$

Depending on the reaction pathway and the form of deposited carbon, deactivation of the catalyst may occur due to blockage of macro- and micro-gas diffusion channels, growth of carbon-whiskers, strong chemisorption of carbon-monolayers or complete encapsulation of the metal particles (1). Generally, this causes rapid and irreversible degradation of the cell. Several studies were therefore dedicated to investigate the influences of different operating conditions to prevent and remove coking. Based on thermodynamic calculations of the $\mathrm{C}-\mathrm{H}-\mathrm{O}$ system high steam-to-carbon ratios and higher operating temperature are certainly advantageous (2). Furthermore, operating the YSZ 
based cells at higher current density helps to prevent coking due to the naturally caused higher $\mathrm{O}^{2-}$ flux which favours oxidization of the present carbon species (3). Thus, SOFCs are typically operated at high steam-to-carbon ratios $(\mathrm{S} / \mathrm{C} \geq 2)$ to prevent carbon deposition. However, even though the thermodynamic limit offers a good guideline for a safe operating window of SOFC operation (4), studies of specific limits regarding the S/C are still controversial. Various studies observed carbon deposition even in the carbon-free regions of the $\mathrm{C}-\mathrm{H}-\mathrm{O}$ diagram $(5,6)$ while other studies showed possible operation of SOFCs in carbon deposition regions with limited evidence of carbon-deposition $(7,3)$.

Only few studies include experimental reliable monitoring tools to allow early detection of developing detrimental faults - 'hard-failures' - such as carbon deposition. Hence, this study simulates the break-down of the external steam supply under operation, leading to conditions at which carbon depositions takes place. Via different monitoring tools i.e. fuel electrode inlet temperature measurements, cell voltage monitoring and insitu electrochemical impedance spectroscopy it was possible to track the development of carbon deposition in the fuel electrode structure and thus allowed exploration of possible counteracts before detrimental failure occurs.

\section{Experimental}

\section{$\underline{\text { Cell specification and electrochemical measurement }}$}

Start-up. The single cell test was carried out on a planar, fuel electrode supported $\mathrm{Ni} / Y S Z$ based SOFC. In detail, the cells consisted of an approx. $300 \mu \mathrm{m}$ thick porous $\mathrm{Ni} / 3 \mathrm{YSZ}$ support on a 12-15 $\mu \mathrm{m} \mathrm{Ni/8YSZ} \mathrm{electrode} \mathrm{and} \mathrm{a} 10 \mu \mathrm{m}$ YSZ electrolyte. As oxygen electrode a $\sim 20 \mu \mathrm{m}$ thick LSM/YSZ composite electrode was applied. Detailed cell fabrication procedure and microstructural properties of the cells can be found in (8).

The testing procedure started by heating the single cell to $850^{\circ} \mathrm{C}$ for sealing and reduction. The $\mathrm{NiO}$ of the support and fuel electrode was reduced for $2 \mathrm{~h}$ in a 9:91 $\mathrm{H}_{2}: \mathrm{N}_{2}$ gas mixture at $201 \mathrm{~h}^{-1}$ and completed for $1 \mathrm{~h}$ in pure $\mathrm{H}_{2}$ at $20 \mathrm{l} \mathrm{h}^{-1}$ at the same temperature. After reduction the cell was initially characterized by iV-curves and electrochemical impedance spectroscopy (EIS) at open-circuit voltage (OCV) and different gas compositions to the fuel and oxygen electrode. The characterizations were performed at 850,800 and $750^{\circ} \mathrm{C}$.

Long-term test before the 'hard-failure' test. In a $900 \mathrm{~h}$ long-term test the cell was subjected to reforming conditions at $750^{\circ} \mathrm{C}$ by supplying a fuel gas mixture of $\mathrm{CH}_{4} / \mathrm{H}_{2} \mathrm{O}$ $(\mathrm{S} / \mathrm{C}=1.2)$ to the fuel electrode at a current density $(i) 0.75 \mathrm{~A} \mathrm{~cm}^{-2}$ and a fuel conversion of $30 \%$. EIS under a current load of $0.75 \mathrm{~A} \mathrm{~cm}^{-2}$ were recorded every $24 \mathrm{~h}$ during durability testing. $\mathrm{O}_{2}$ was fed to the oxygen electrode during the long-term test to assure negligible degradation of this electrode (9). The initial characterization was repeated after the galvanostatic durability test.

'Hard-failure' test - operation on methane only. After the first $900 \mathrm{~h}$ the steam supply was stopped under current load to simulate the break-down of the external steam gas supply and the cell was consequently operated on methane. In order study the effects of one specific fault i.e. 'carbon deposition', the methane gas flow was simultaneously increased to avoid fuel starvation.

After changes of cell voltage, fuel inlet temperature and electrochemical performance (evaluated via EIS) had been observed, the cell was returned to the original long-term test 
conditions for 5 days. Thereafter the 'hard-failure' test (stop of steam supply) was repeated.

\section{Electrochemical Impedance Spectroscopy (EIS)}

EIS spectra were recorded with a Solartron 1260 A frequency analyzer in a frequency range from $96.5 \mathrm{kHz}$ to $0.1 \mathrm{~Hz}$ and 12 points/decade. For visualization of the EIS an in-house developed Python based software Ravdav (10) was used. Distribution of relaxation times (DRT) was applied for qualitative analysis of characteristic frequency ranges for different processes and for interpretation of changes of each process over time (11). The high frequency response (arc at 11-40 kHz) has been assigned to the ionic transport in the YSZ-matrix of Ni-YSZ and LSM-YSZ electrodes (12). The impedance responses attributed to electrochemical processes appear at $1-4 \mathrm{kHz}$ for the fuel electrode and at $0.1-1 \mathrm{kHz}$ for oxygen electrode, respectively. Moreover, impedance originating from fuel diffusion and fuel conversion appear in a frequency range below $100 \mathrm{~Hz}$. $(12,13)$.

\section{Results and discussion}

The long-term testing was performed at conditions for which there - according to thermodynamic calculations - should be no C-deposition (2).

After long-term testing, the cell was subjected to operation on methane alone to deliberately cause carbon deposition (14) and investigate the possibility of early failure detection and a recovery strategy. For better visualization of the sequences the first $900 \mathrm{~h}$ of test and EIS characterizations of the long-term test are not included in Figure 1.

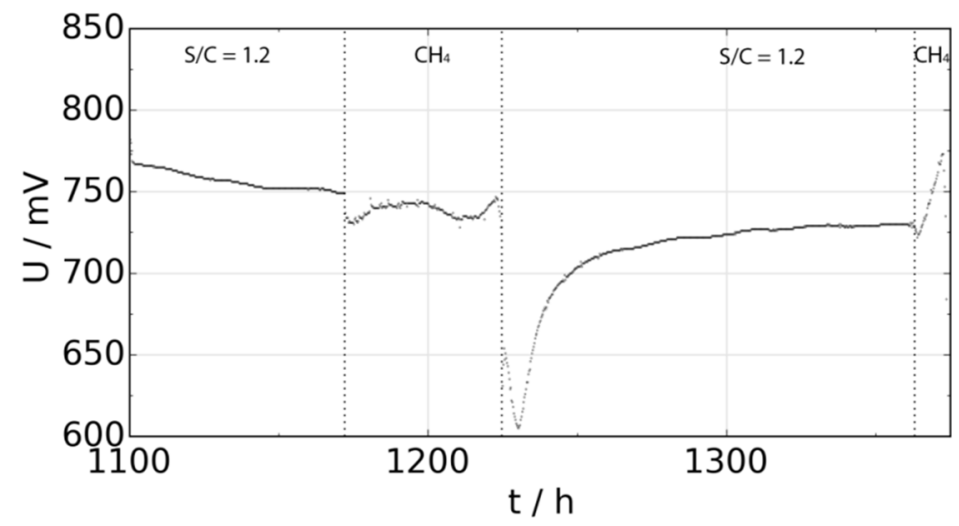

Figure 1 Cell voltage measurement during 'hard failure' testing.

\section{$\underline{\text { First 'hard-failure' test }}$}

After long-term testing under steam reforming conditions of methane the cell was subjected to operation on methane only. Figure 2 a shows the cell voltage and temperature measurements during the 'hard-failure' testing sequence (see Figure 1 for the overall period). 

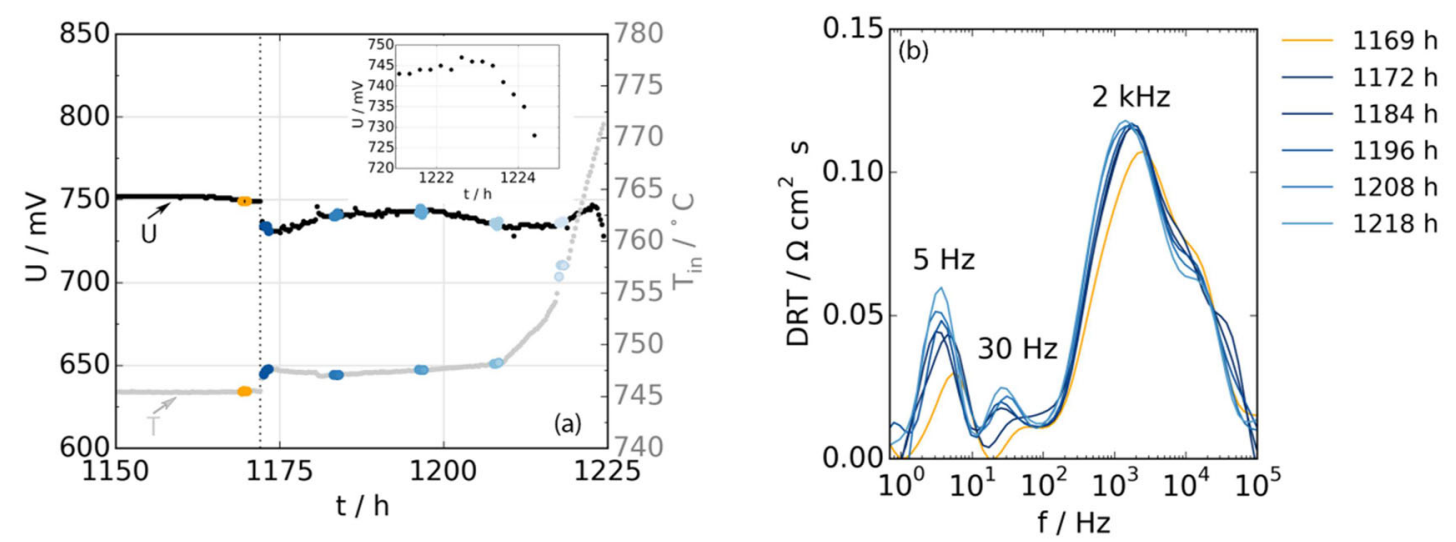

Figure 2 Measured cell voltage and fuel inlet temperature for cell operation on $\mathrm{CH}_{4}$ with an insert of the last $4 \mathrm{~h}$ of the 'hard failure' test (a) and DRT plots of EIS measurements over time (b). The times for recording EIS are indicated by dots in (a).

At the beginning of the 'hard-failure' test, an immediate cell voltage drop $(\Delta \mathrm{V}=12$ $\mathrm{mV}$ ) at a constant current load of $0.75 \mathrm{~A} \mathrm{~cm}^{-2}$ occurred and the cell operation with methane fuel was accompanied by higher noise-to-signal ratio of the cell voltage measurement. Additionally, temperature monitoring of the fuel cell inlet showed a small temperature increase of $2{ }^{\circ} \mathrm{C}$. Comparable observation of a cell voltage drop and temperature increase was reported by Subotic et al. (15) in a similar experiment performed with a diesel reformate fuel. After $36 \mathrm{~h}$ of the 'hard-failure' test, a temperature increase of $25^{\circ} \mathrm{C}$ close to the fuel inlet was detected and finally, after $c a .50 \mathrm{~h}$ while operating on methane the cell voltage started to decrease rapidly (see inserted image Figure 2a). In order to prevent the cell from fatal damage due to low voltage, the steam supply was started again.

To get more detailed insight into the cell degradation while performing the "hardfailure' test, EIS over time were performed (see Figure $2 b$ for DRT representation of the EIS measurement and the times of the EIS measurements are additionally indicated by dots in Figure 2a).

At the beginning of the 'hard-failure' test distinct changes corresponding to fuel conversion, fuel diffusion (low frequency range) and electrochemical activity (high frequency) was obvious. This effect is to be expected due to change and operation on a different fuel gas (compare yellow and first blue DRT in figure $2 b$ ).

However, the evolution of the individual peaks occurred differently over time: First, the process related to the fuel gas diffusion through the porous electrode at $20-30 \mathrm{~Hz}$ (16) (diffusion resistance) started to increase steadily after the fuel change. In the first $36 \mathrm{~h}$ of methane operation the diffusion resistance approx. doubled $\left(0.004-0.008 \Omega \mathrm{cm}^{2}\right)$ and increased further to $0.010 \Omega \mathrm{cm}^{2}$ until stopping the 'hard-failure' test. Since the observed increase can serve as indicator for blocked pores $(17,18)$, it suggests the initiation of carbon deposition inside the fuel electrode structure.

The second low frequency process related to the gas composition changes (conversion resistance, $5 \mathrm{~Hz}$ ), showed only a minor change in the first $36 \mathrm{~h}$ of the test $\left(0.024 \Omega \mathrm{cm}^{2} \pm 4 \%\right)$, and significantly increased by $33 \%$ thereafter. This increase seems to happen concurrently with the detected increase of temperature at the fuel inlet. As the temperature sensor was placed in the oxygen electrode chamber close to the fuel inlet, the 
occurrence of direct oxidation of $\mathrm{CH}_{4}$ due to cracks $\left(-802.6 \mathrm{~kJ} \mathrm{~mol}^{-1}\right)$ may explain the increase of temperature and gas composition changes in the fuel electrode chamber.

Yet the third process at high frequency - the electrochemical activity - did not seem to be severely affected $\left(0.131 \Omega \mathrm{cm}^{2} \pm 3 \%\right)$ over the complete period of the 'hard failure test' until the cell voltage decreased significantly (see Figure $2 \mathrm{~b}$ ). In other words, the first indication of carbon deposition appears as blocking of pores in the anode, while the electrochemical reactions (reflected by the corresponding EIS frequency response at 2 $\mathrm{kHz}$ and the constant cell voltage) are not affected, initially.

Hence, mainly carbon deposition occurring in the support layer of the electrode can be expected to be associated with the time-dependent increase of the diffusion resistance. Whereas the subsequent (ca. $36 \mathrm{~h}$ ) temperature and gas conversion resistance increase indicate a possible mechanical failure. The deactivation of the active layer may be then visible by the significantly dropping cell voltage.

Post-mortem investigations of cells at different stages of the experiment will give a more detailed insight into the evolvement of carbon deposition in the anode supported cell structure and are planned for future tests.

\section{$\underline{\text { Return to nominal conditions - methane/steam mixture as inlet gas }}$}

After the 'hard-failure' test the fuel was set back to the initial long-term test conditions; meaning $4.8 \mathrm{l} / \mathrm{h} \mathrm{H} \mathrm{H}_{2} \mathrm{O}$ and $4 \mathrm{l} / \mathrm{h} \mathrm{CH}$. Figure $3 \mathrm{a}$ shows a magnification of Figure 1 corresponding to this period. The fuel inlet temperature decreased rapidly (reintroduction of steam) whereas the cell voltage showed an initial drop of $73 \mathrm{mV}$. This voltage drop corresponds approx. to the OCV decrease due to the gas change $\left(\mathrm{OCV}_{\mathrm{CH} 4}=1.163 \mathrm{~V}\right.$ vs. $\mathrm{O}_{2}$ and $\mathrm{OCV}_{\text {reformate gas }}=1.100 \mathrm{~V}$ vs. $\mathrm{O}_{2}$ as calculated from the Nernst equation). Then the voltage decreased slowly further to $605 \mathrm{mV}(\Delta \mathrm{V}=122 \mathrm{mV})$ and finally showed a gradual increase over time (see Figure 3a). The resulting steady voltage increase after the fast initial drop suggests that the cell is successively freed from $\mathrm{C}$-deposits over time. However, the cell voltage did not reach the initial conditions after the cell voltage showed stabilization. An overall voltage loss of $18 \mathrm{mV}$ compared to the initial voltage before methane operation was measured, indicating a not completely reversible recovery after the fault.
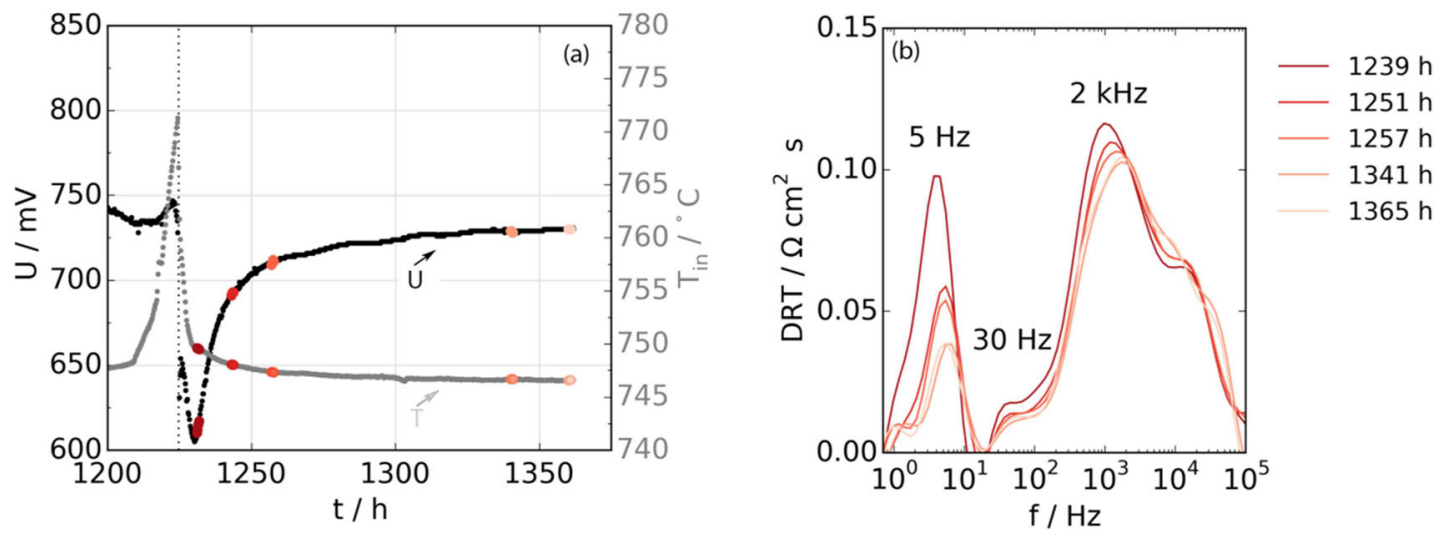

Figure 3 Measured cell voltage and fuel inlet temperature for cell operation at nominal operation conditions after 'hard-failure' test (a) and DRT plots of EIS measurements over time (b). The times for recording EIS are indicated by dots in (a). 
The changes over time were again monitored by EIS (see Figure 3b for DRT representation of the EIS measurements and the times are indicated via red marks in Figure 3a). The increase of steam flow initially $(\leq 10 \mathrm{~h})$ results in a very complex composition of the fuel gas, indicated by the changes of the gas conversion resistance (not shown here). After $22 \mathrm{~h}$ the fuel composition seemed fairly stable but the gas conversion resistance still decreased whereas the diffusion resistance showed no significant change within ca. $100 \mathrm{~h}$ of testing at nominal conditions. On the other hand, the resistance of processes in the high frequency region 1-3 kHz corresponding to the electrochemical active sites decreased steadily with time.

\section{$\underline{\text { Second 'hard-failure' test }}$}

In the last sequence of the experiment the cell was operated again on methane only. During the first $2 \mathrm{~h}$ of the second 'hard-failure' test the temperature remained stable and thereafter increased again about $25^{\circ} \mathrm{C} .10 \mathrm{~h}$ after the second stop of steam supply the cell voltage decreased rapidly again and destructive cell failure occurred (see Figure 4).
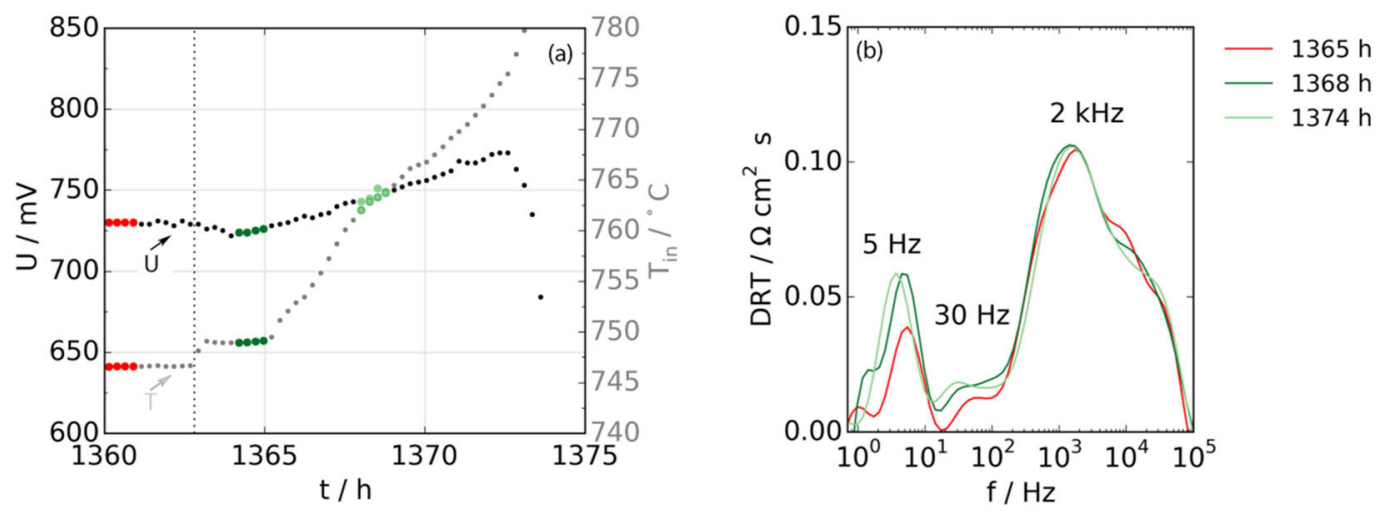

Figure 4 Measured cell voltage and fuel inlet temperature for $2^{\text {nd }}$ cell operation on $\mathrm{CH}_{4}$ (a) and DRT plots of EIS measurements over time (b). The times for recording EIS are indicated by dots in (a).

Consequently, the electrochemical activity of the cell responded faster to the second fault introduction. This is an indication for an incomplete recovery from the first fault segment. Particularly, the period where the diffusion in the pores was affected by carbon deposition seem to have not occurred, probably because there was still carbon deposited at those sites. An illustration of the assumed underlying processes during 'hard-failure' and 'recovery' are shown in Figure 5. 


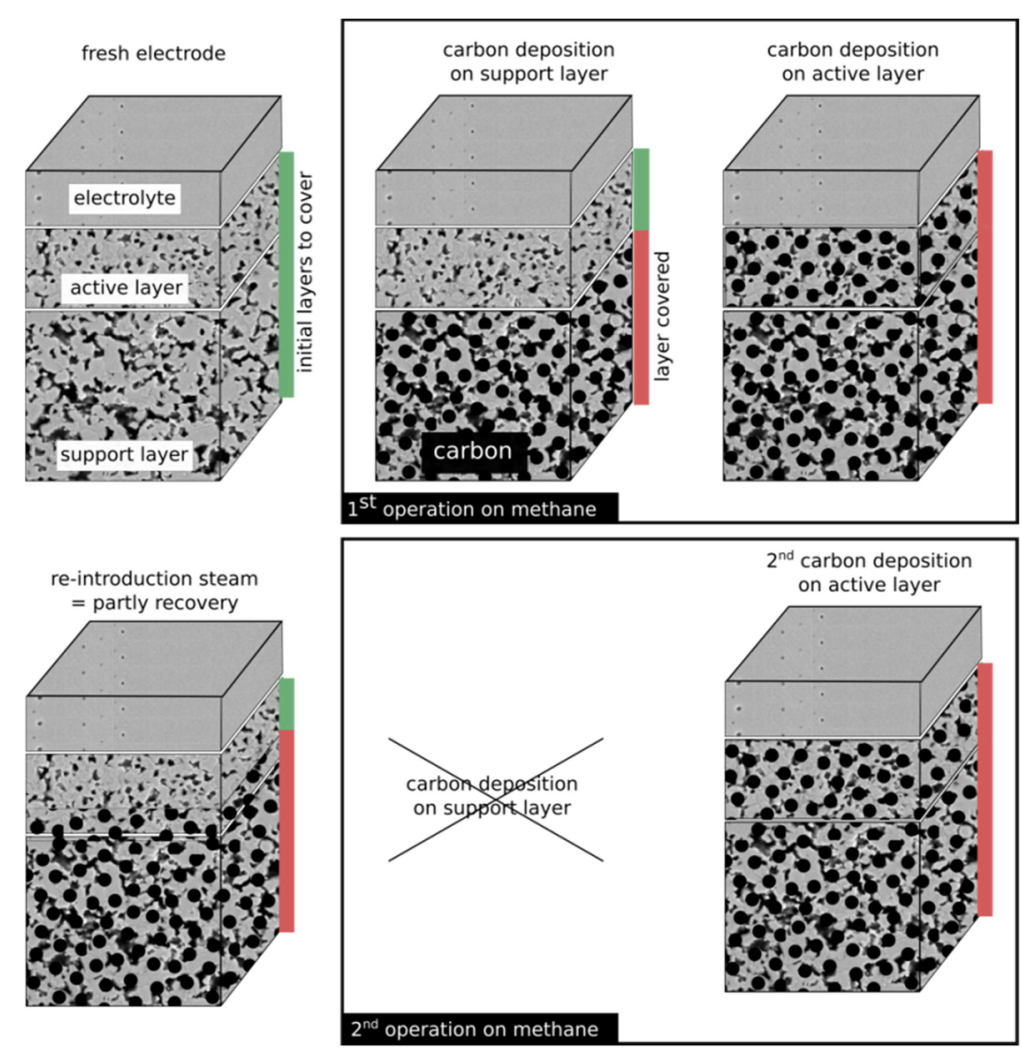

Figure 5 Illustration of the proposed carbon deposition process during methane operation and after re-introduction of steam in the support and active layer of the Ni/YSZ supported SOFC.

\section{Conclusion}

This study simulates a failure where the steam supply is interrupted and the SOFC is run on methane only and a partly 'recovery' on the running SOFC by re-starting the steam supply.

The fault introduction leads to operation at conditions where carbon deposition can be expected. Regularly performed EIS measurements showed a time-dependent increase of the impedance in the low frequency region which could be correlated to carbon deposition in the individual layers of the fuel electrode support (i.e. change in conditions limiting physical processes), while the electrochemical activity remained intact. After approx. $50 \mathrm{~h}$ of the operation on methane a fast decrease of the cell voltage was observed, suggesting the complete deactivation of the entire cell due to carbon deposition.

Moreover, the recovery feasibility of the cell via the restart of the external steam supply was investigated. The re-introduction of steam resulted in a partly recovery attributed the oxidation of C-deposits in the active layer of the cell, while the carbon was not (completely) removed from the support layer. 


\section{Acknowledgements}

The authors would like to thank colleagues at DTU Energy Conversion for technical assistance especially H. Henriksen. Furthermore, funding by the European project EUINSIGHT (grant agreement No. 735918) is gratefully acknowledged.

\section{References}

1. P. Boldrin, E. Ruiz-Trejo, J. Mermelstein, J. M. Bermédez Menúndez, T. Ramárez Reina, N. P. Brandon, Chem. Rev., 116, 13633 (2016).

2. K. Sasaki, Y. Teraoka, J. Electrochem. Soc., 150, A885 (2003).

3. Y. Lin, Z. Zhan, J. Liu, S. A. Barnett, Solid State Ionics, 176, 1827 (2005).

4. T.-I. Tsai, Ph.D. dissertation, University of Birmingham, (2015).

5. N. Laosiripojana, S. Assabumrungrat, J. Power Sources, 163, 943 (2007).

6. T. Takeguchi, Y. Kani, T. Yano, R. Kikuchi, K. Eguchi, K. Tsujimoto, Y. Uchida, A. Ueno, K. Omoshiki, M. Aizawa, J. Power Sources, 112, 588 (2002).

7. H. Madi, S. Diethelm, J. Van herle, N. Petigny, ECS Trans., 57, 1517 (2013).

8. A. Hauch, C. Birkl, K. Brodersen, P. S. Jørgensen, Proceedings of 10th European SOFC \& SOE Forum, (2012).

9. A. Hagen, Y. L. Liu, R. Barfod, P. V. Hendriksen, J. Electrochem. Soc., 155, B1047 (2008).

10. C. Graves, Ravdav Data Analysis Software, Version 0.9.8, (2012).

11. H. Schichlein, A. C. Müller, M. Voigts, A. Krügel, E. Ivers-Tiffée, 32, 875 (2002).

12. R. Barfod, M. Mogensen, T. Klemensø, A. Hagen, Y.-L. Liu, P. Vang Hendriksen, J. Electrochem. Soc., 154, B371 (2007).

13. T. Ramos, M. Søgaard, M. B. Mogensen, J. Electrochem. Soc., 161, F434 (2014).

14. Y. Jiao, L. Zhang, W. An, W. Zhou, Y. Sha, Z. Shao, J. Bai, S.-D. Li, Energy, 113, 432 (2016).

15. V. Subotic, C. Schluckner, J. Mathe, J. Rechberger, H. Schroettner, C. Hochenauer, J. Power Sources, 295, 55 (2015).

16. S. Primdahl, M. Mogensen, J. Electrochem. Soc., 146, 2827 (1999).

17. H. Sumi, K. Ukai, Y. Mizutani, H. Mori, C.-J. Wen, H. Takahashi, O. Yamamoto, Solid State Ionics, 174, 151 (2004).

18. T. Chen, W. G. Wang, H. Miao, T. Li, C. Xu, J. Power Sources, 196, 2461 (2011). 